\title{
None Are Protected If All Are Not Protected
}

Julia Koehler, MD

The apparent on-camera murder by slow asphyxiation of George Floyd, arrested for an alleged \$20 forgery, drives ongoing protests throughout Massachusetts. Together with yet more shooting deaths of Black people in recent weeks, it highlights not only how acceptance of police violence against Black people was written into law. It also comes at a time when the vastly disproportionate rates of COVID-19 infection and death in Massachusetts' Black and immigrant communities have risen into public awareness, even as our state's distinction of having the fourth-highest death rate in the country has not.

\section{"Together with yet more shooting deaths of Black people in recent weeks, it highlights not only how acceptance of police violence against Black people was written into law. It also comes at a time when the vastly disproportionate rates of COVID-19 infection and death in Massachusetts' Black and immigrant communities have risen into public awareness, even as our state's distinction of having the fourth highest death rate in the country has not."}

We posit that devaluation of Black and immigrant lives is implicit in policies that accept these infection and death rates as inevitable and that successful control of the pandemic here in Massachusetts hinges on political decisions to proactively remedy the factors that render these communitie so vulnerable. We call on elected officials at every level of our Commonwealth, starting with Governor Baker, to focus on these policies with maximal urgency as reopening is being advanced. This will require inviting representatives of these communities to the table, as the CEOs who currently populate the governor's reopening board lack the knowledge of their life circumstances that representatives like Gladys Vega of the Chelsea Collaborative and Reverends Ray and Gloria Hammond of Bethel AME Church can bring. It is the voices of the affected communities that can best clarify the realities excluded from Governor Baker's statement that safe reopening hinges on personal responsibility. Black and immigrant individuals desire nothing more than to protect themselves but must place themselves into dangerous environments to put food on the table and keep a roof over their heads.

Three parts of daily life put Black and immigrant men and women at stark risk of infection: work, transportation, and home. Workplaces of frontline low-income workers have been unsafe since the beginning of the epidemic. As some examples, grocery store cashiers long lacked sneeze guards and masks; hospital janitors, nursing home staff, as well as home care attendants, lacked training in the use of personal protective equipment (if they even had such equipment available); bus drivers lacked enclosures; and food production workers were closely crowded together. Current policies, in which detailed protective measures at each type of workplace are not mandated, still drive businesses to skirt safety measures, because the most conscientious businesses are financially penalized. Occupational health experts, workers' centers, and unions know the workplace realities on the ground to formulate needed detailed guidelines. Employees requesting adherence to guidelines must be protected from retaliation. In current circumstances, with rampant food insecurity and with the specter of an employer calling ICE to rid himself of a sick undocumented worker, employees are afraid to ask for adherence to workplace guidelines if they are not robustly shielded from dismissal or worse. Presumption of occupational exposure of COVID-19 passed into law or ordered in 12 states, rewards businesses that protect their workers rather than punishing them for doing so, and enables employees to stay home as long as they are infectious.

Unsafe transportation endangers not only MBTA staff but also riders who must get to work. In fact the undocumented, who comprise a significant number of essential workers, still lack the right in our state to take a driving test and obtain a drivers' license; we call on the governor to endorse the Work and Family Mobility Act that would unite us with our neighbors Connecticut, New York and Vermont in disconnecting drivers' licenses from immigration status. Similarly, the Safe Communities Act, delinking public safety policework, like traffic monitoring by State Police, from immigration enforcement, can help foster more trust of immigrant communities in state authorities. The absence of this trust currently makes effective COVID-19 contact tracing impossible. Safe transport will require constant monitoring of conditions on trains and buses and correction of deficits because it is the essential workers who cannot work from home.

Higher risks at home are the third arena in which Black and immigrant communities find themselves in harm's way from COVID-19. Our Commonwealth has tolerated significantly higher levels of pollution in their residential areas, increasing their risk for chronic lung conditions that contribute to more severe disease. Skyrocketing housing costs also force families to choose between intense crowding or homelessness. Families who now have no food are even harder pressed for rent. An explosion of evictions, foreclosures, and family homelessness threatens to throw accelerant on the epidemic unless tenants, homeowners, and small landlords are further protected before the current moratorium expires.

A second wave of infections would be devastating not just for the health and life of all Massachusetts residents, including the residents of sheltered towns who count on the health of their nannies, 
housecleaners, and food workers. (This was amply demonstrated by the second surge in Singapore, driven by infections among low-income migrant workers.) It would also deeply disrupt the operations of small businesses, of the farms in the Western part of our state, the ability of daycare centers and schools to plan and to function, and hence the financial lifeblood of many people in our state. The idea that a second wave is inevitable is deeply harmful, as the Massachusetts High Technology Council has pointed out. Preventing more infections is not only right because every human life is precious. It is also critical for a strong economy.

"We can be hopeful that similarly beneficial outcomes result from our current COVID-19 pandemic, whether that be an acceleration of research into therapeutics and vaccines, or improved preparedness for the next pandemic yet to emerge."

If our affirmation that Black lives matter and that we are a welcoming state is more than a beautiful sentiment but is meant to truly protect the lives of those who have already suffered so disproportionately in the epidemic, concrete steps are needed now. The voices and expertise of the most intensely impacted groups must be called on. For COVID-19, justice and science converge: none are protected if all are not protected.

\section{Julia Koehler, MD}

Pediatric Infectious Diseases specialist and Assistant Professor of Pediatrics, Harvard Medical School

Robert Husson, MD

Pediatric Infectious Diseases specialist and Professor of Pediatrics, Harvard Medical School

\section{Regina LaRocque, MD MPH}

Adult Infectious Diseases specialist and Associate Professor of Medicine, Harvard Medical School

\section{References:}

1. https://www. washingtonpost.com/politics/currentlaw-gives-police-wide-latitude-to-use-deadlyforce/2014/08/28/768090c4-2d64-11e4-994d202962a9150c story.html

2. https://www. theatlantic.com/politics/archive/2019/08/how- courts-judge-police-use-force/594832/

3. https://www.nytimes.com/interactive/2020/us/ massachusetts-coronavirus-cases.html

4. https://www.bostonglobe.com/2020/05/09/nation/disparitiespush-coronavirus-death-rates-higher/

5. https://www.bostonmagazine.com/news/map-coronaviruscases-by-county-massachusetts/

6. https://www.bostonglobe.com/2020/05/09/nation/disparitiespush-coronavirus-death-rates-higher/

7. https://www.bostonglobe.com/2020/04/26/metro/savingchelseal

8. http://www.bethelame.org/our-pastors

9. https://www.boston.com/news/coronavirus/2020/05/18/ charlie-baker-massachusetts-reopening-plan-livestreamvideo

10. http://www.masscosh.org/publications/featured-articles/ comprehensive-information-covid-19

11. https://www. southcoasttoday.com/news/20200413/newbedford-seafood-workers-report-overcrowding-poorsanitation

12. http://www.masscosh.org/

13. https://www.masslegalservices.org/content/worker-centersmassachusetts

14. https://www.1199seiu.org/massachusetts

15. https://www.washingtonpost.com/national/in-an-immigrantcommunity-battling-coronavirus-essential-meansvulnerab/e/2020/05/08/c25cdb4e-8e1e-11ea-a9c073b93422d691 story.html

16. https://www.wbur.org/news/2017/05/17/ice-arrest-workerscomp

17. https://www.jdsupra.com/legalnews/illinois-legis/aturepasses-covid-19-78617/

18. https://www.ncsl.org/research/labor-and-employment/covid19-workers-compensation.aspx

19. https://www.gazettenet.com/Bill-to-allow-undocumentedresidents-drivers-licenses-reported-out-ofcommittee-32524158

20. https://www.miracoalition.org/our-work/safe-communities/

21. https://www.t4ma.org/covid-19

22. https://www.mass.gov/info-details/ago-environmentaljustice-brief

23. http://www.clvu.org/covid19

24. https://www.bostonglobe.com/2020/04/20/business/bakersigns-bill-blocking-evictions-during-coronavirus/

25. https://www.bloomberg.com/news/articles/2020-04-28/virussurge-in-southeast-asia-migrant-workers-serves-as-warning

26. http://www.mhtc.org/events/covid-19-response/

The author has no conflicts to disclose

NT

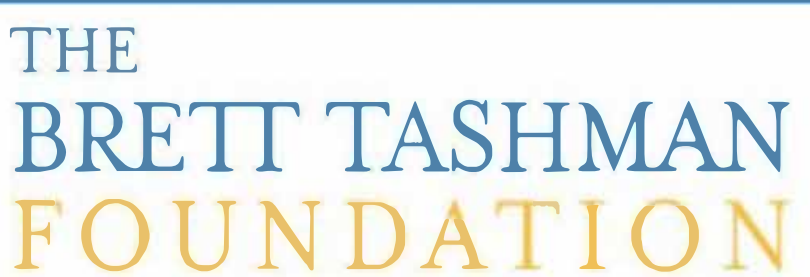

The Brett Tashman Foundation is a 501()(3) public charity. The mission of the Foundation is to find a cure for Desmoplastic Small Cell Round Tumors (DSRCT). DSRCT is an aggressive pediatric cancer for which there is no cure and no standard treatment. 100 percent of your gift will be used for research. There is no paid staff. To make your gift or for more information, go to "TheBrettTashmanFoundation.org" or phone (909) 981-1530. 

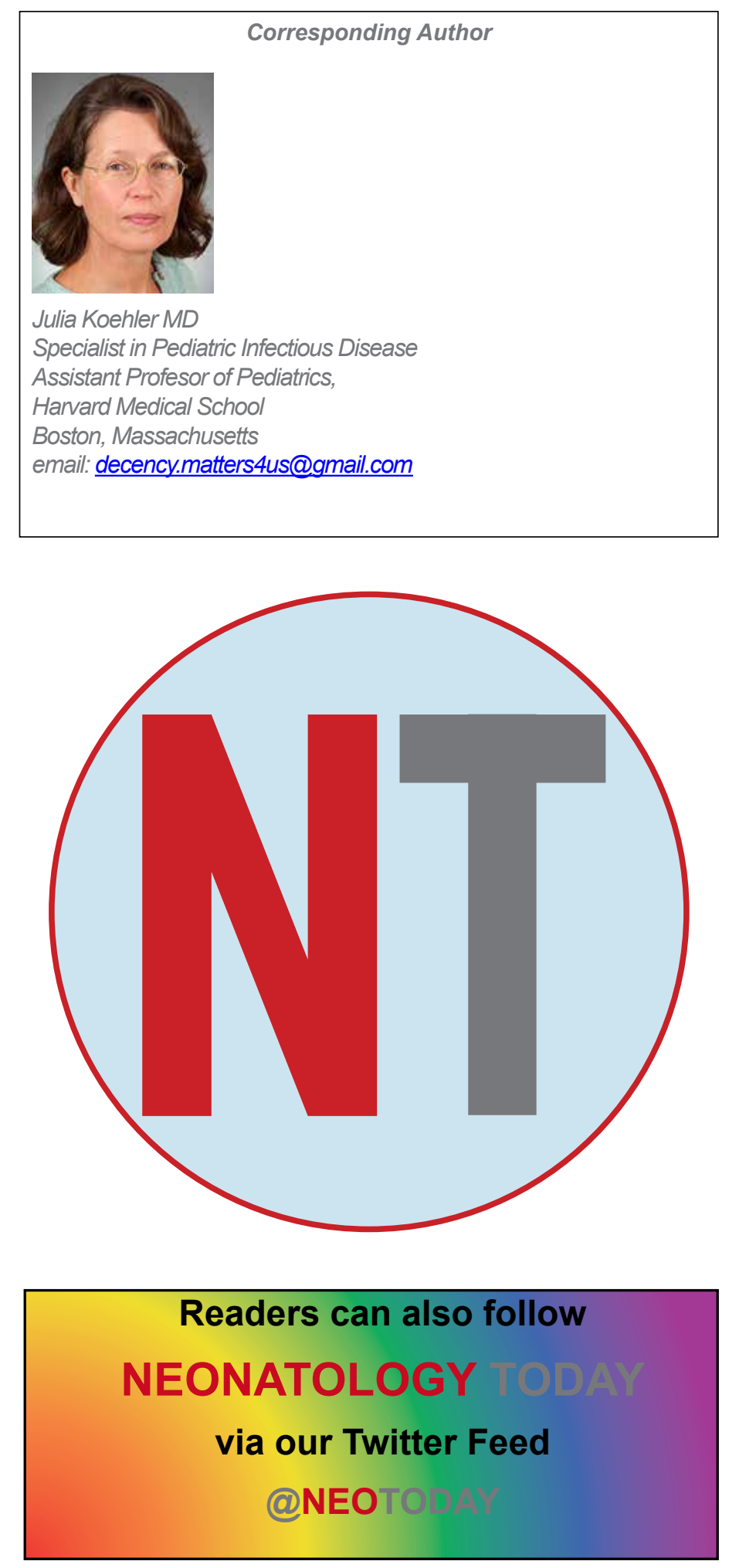

\section{OPIOIDS and NAS}

When reporting on mothers, babies, and substance use

\section{LANGUAGE MATTERS}

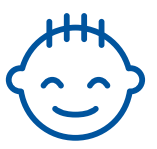

\section{I am not an addict.}

I was exposed to substances in utero. I am not addicted. Addiction is a set of behaviors associated with having a Substance Use Disorder (SUD).

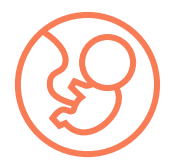

I was exposed to opioids.

While I was in the womb my mother and I shared a blood supply. I was exposed to the medications and substances she used. I may have become physiologically dependent on some of those substances.

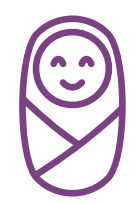

NAS is a temporary and treatable condition.

There are evidence-based pharmacological and non-pharmacological treatments for Neonatal Abstinence Syndrome.

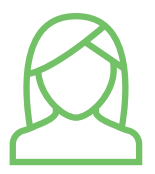

My mother may have a SUD.

She might be receiving Medication-Assisted Treatment (MAT). My NAS may be a side effect of her appropriate medical care. It is not evidence of abuse or mistreatment.

My potential is limitless.

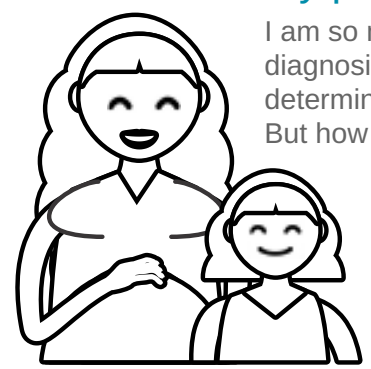

more than my NAS mosis. My drug exposure will not etermine my long-term outcomes. you treat me will. When you invest in my family's health and wellbeing by supporting Medicaid and Early Childhood Education you can expect that I will do as well as any of my peers!

Learn more about

Neonatal Abstinence Syndrome at wWW.nationalperinatal.org

NEONATOLOGY TODAY is interested in publishing manuscripts from Neonatologists, Fellows, NNPs and those involved in caring for neonates on case studies, research results, hospital news, meeting announcements, and other pertinent topics.

Please submit your manuscript to: LomaLindaPublishingCompany@gmail.com 